\title{
First record of Ticapimpla vilmae Gauld, 1991 (Hymenoptera, Ichneumonidae, Pimplinae) from Brazil
}

\author{
Loffredo, APS. ${ }^{\mathrm{a} *}$ and Penteado-Dias, AM. ${ }^{\mathrm{b} *}$ \\ aPrograma de Pós-Graduação em Ecologia e Recursos Naturais, \\ Universidade Federal de São Carlos - UFSCar, \\ Rod. Washington Luís, Km 235, CEP 13565-905, São Carlos, SP, Brazil

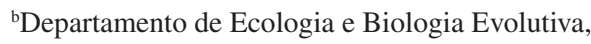 \\ Universidade Federal de São Carlos - UFSCar, \\ Rod. Washington Luís, Km 235, CEP 13565-905, São Carlos, SP, Brazil. \\ *e-mail: ap_loffredo@yahoo.com.br, angelica@ufscar.br
}

Received July 10, 2008 - Accepted July 15, 2008 - Distributed November 30, 2008

(With 2 figures)

Studying material proceeding from sampling done during the project "Riqueza e diversidade de Hymenoptera e Isoptera ao longo de um gradiente latitudinal de Mata Atlântica - a floresta úmida do leste do Brasil" supported for Fundação de Amparo à Pesquisa do Estado de São Paulo, was found one Ticapimpla vilmae specimen. This genus is caracterized by having a developed submetapleural carina and a densely hirsute mesoscutum. The only species in this genus was described by Gauld (1991) in Costa Rica. Were collected two females with Malaise trap in Golfo Dulce forestry Reserve, in an area relatively intact.

From Mata da Esperança in Ilhéus, State of Bahia, Brazil, at the $14^{\circ} 47^{\prime} 47^{\prime}$ ' S and 39 $03^{\circ}$ '56' W, 0-200 m of altitude, one female specimen was obtained from Malaise trap in 18-21.V.2002. The specimen is deposited in the collection (DCBU) of Universidade Federal de São Carlos, Departamento de Ecologia e Biologia Evolutiva, São Carlos, São Paulo, Brazil. The specimen studied, presented some variation in coloration: the hind tibia is more extensive blackish, as well the last two tergites of metasoma.

At the first time photographs (Figures 1, 2) of this species are provided. Recently (Loffredo and
Penteado Dias, 2008) Schizopyga, other Pimplinae genus was the first time figured.

In South America there are several other undescribed species (I. Saaksjarvi, pers. comm. apud Gauld and Dubois, 2006). Details about its biology are unknown.

Acknowledgements - To FAPESP (Fundação de Amparo à Pesquisa do Estado de São Paulo, Projeto BIOTA) and CNPq (Conselho Nacional de Desenvolvimento Científico e Tecnológico) for financial support.

\section{References}

GAULD, ID., 1991. The Ichneumonidae of Costa Rica, 1. Memoirs of the AmericanEntomological Institute, vol. 47, p. 1-589.

GAULD, ID. and DUBOIS, J., 2006. Phylogeny of the Polysphincta group of genera (Hymenoptera: Ichneumonidae; Pimplinae): a taxonomic revision of spider ectoparasitoids. The Royal Entomological Society. Systematic Entomology, vol. 31, no. 3 , p. $529-564$.

LOFFREDO, A., SILVA, P. and PENTEADO-DIAS, AM., 2008. First record of Schizopyga Gravenhorst (Hymenoptera, Ichneumonidae, Pimplinae) from Brazil and a description of a new species. Rev. Bras. Biol. = Braz. J. Biol., vol. 68, no. 2, p. $457-458$.
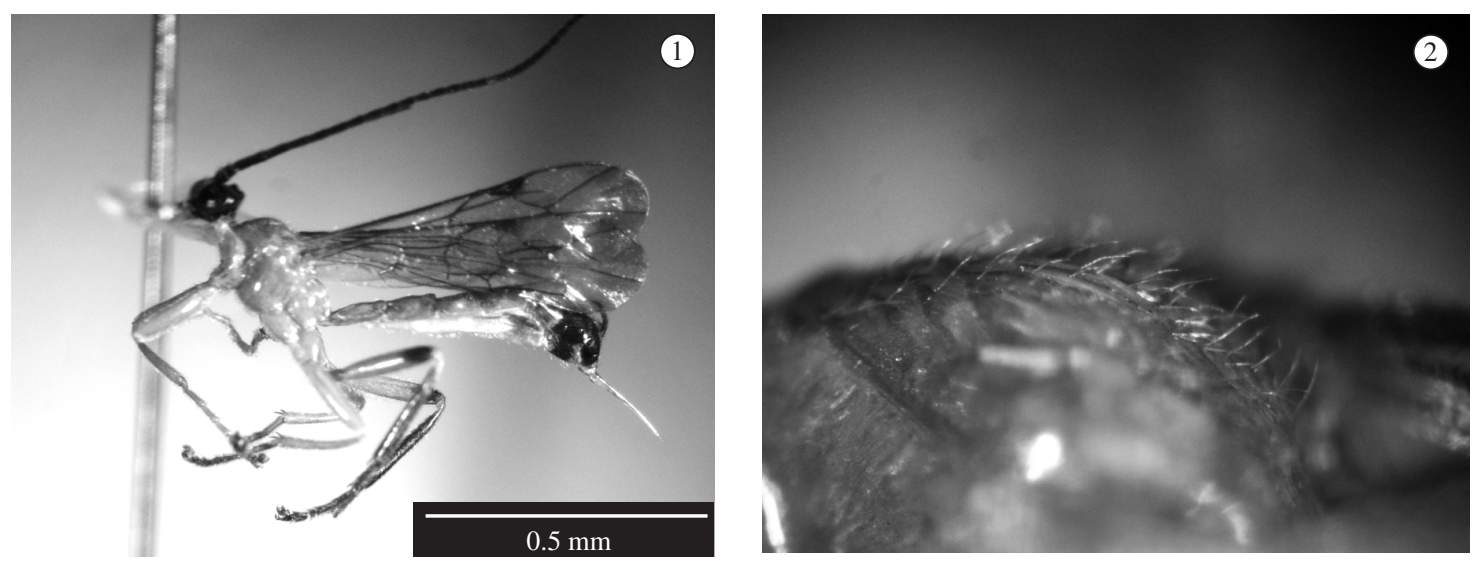

Figures 1-2. Ticapimpla vilmae,.+ 1, habitus; 2 , mesoscutum 